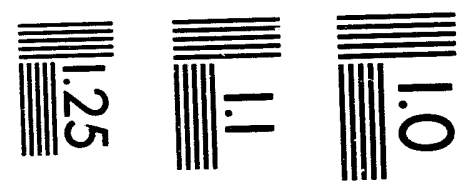

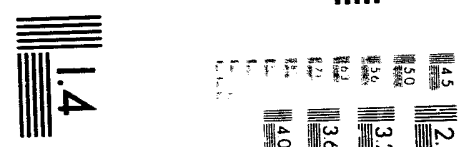

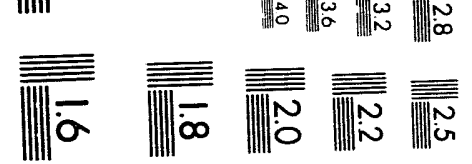



ORNL/ER-195

Energy Systems Environmental Restoration Program ORNL Environmental Restoration Program

\section{Readiness Review Plan for the Interim Remedial Action on Surface Debris in Waste Area Grouping 11 at Oak Ridge National Laboratory, Oak Ridge, Tennessee}

Date Issued-October 1993

Prepared for

U.S. Department of Energy

Office of Environmental Restoration an 1 Waste Management

under budget and reporting code EW 20

OAK RIDGE NATIONAL LABORATORY

Oak Ridge, Tennessee 37831-7101

managed by

MARTIN MARIETTA ENERGY SYSTEMS, INC. for the

U.S. DEPARTMENT OF ENERGY under contract DE-AC05-84OR21400

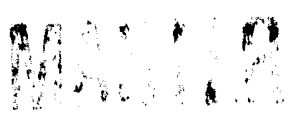


Readiness Review Plan for the Interim Remedial Action of Surface Debris in Waste Area Grouping 11 at Oak Ridge National Laboratory, Oak Ridge, Tennessee

Approvals

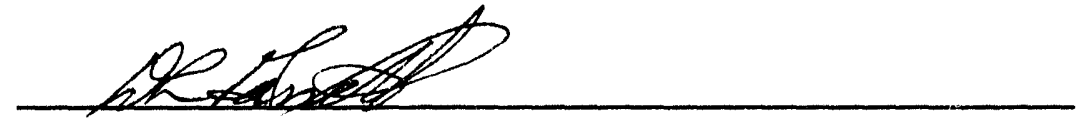

D. L. Garrett, WAG 11 Engineering Project Manager

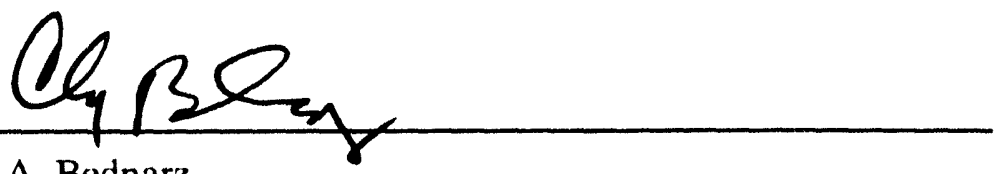

C. A. Bednarz,

WAG 11 Program Manager

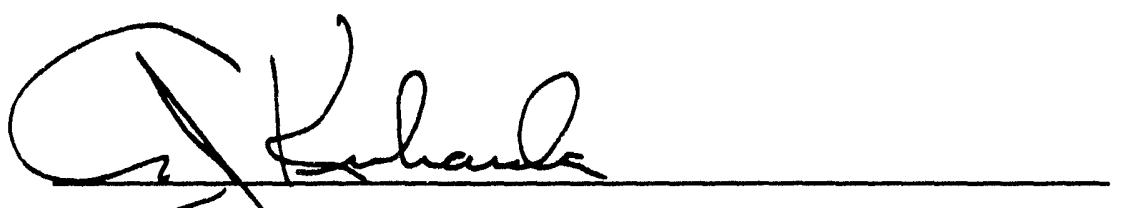

A. Tuhaiqa, Chairman,

Readiness Review Board

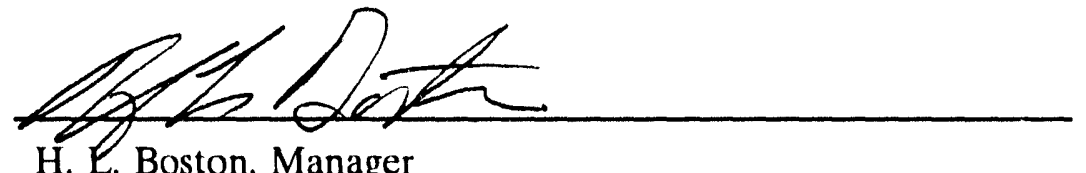

H. E. Boston, Manager

ORNL Environmental Restoration Program

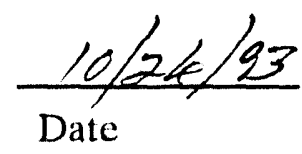

colaelaz.

Date

$10 / 26 / 93$

Date

$10-26-93$

Date

iii 


\section{CONTENTS}

ABBREVIATIONS $\ldots \ldots \ldots \ldots \ldots \ldots \ldots \ldots \ldots \ldots \ldots \ldots \ldots \ldots \ldots \ldots \ldots \ldots$

EXECUTTVE SUMMARY $\ldots \ldots \ldots \ldots \ldots \ldots \ldots \ldots \ldots \ldots \ldots \ldots$

1. INTRODUCTION $\ldots \ldots \ldots \ldots \ldots \ldots \ldots \ldots \ldots \ldots \ldots \ldots \ldots \ldots \ldots$

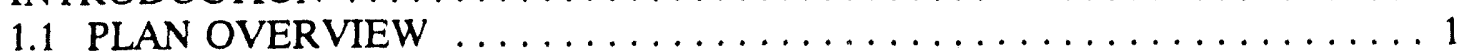

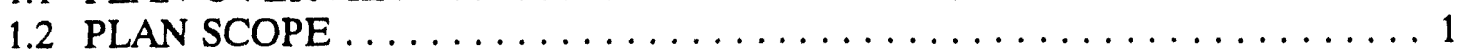

2. PROJECT SUPPORT $\ldots \ldots \ldots \ldots \ldots \ldots \ldots \ldots \ldots \ldots \ldots \ldots \ldots$

3. SITE BACKGROUND AND LOGISTICS OF REMEDIAL ACTION $\ldots \ldots \ldots .4$

4. PROGRAM MANAGEMENT $\ldots \ldots \ldots \ldots \ldots \ldots \ldots \ldots \ldots \ldots \ldots$

4.1 THE ENVIRONMENTAL RESTORATION

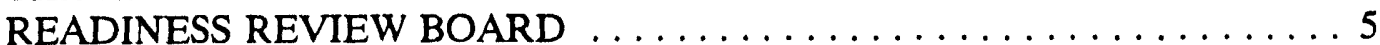

4.1.1 The Readiness Review Board Charter . . . . . . . . . . . . . . 5

4.1.2 Environmental Restoration Program

Site Readiness Review Board Members . . . . . . . . . . . . . . . . 5

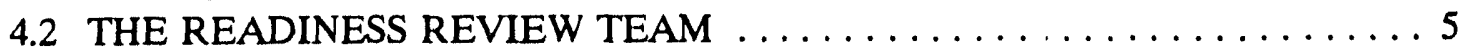

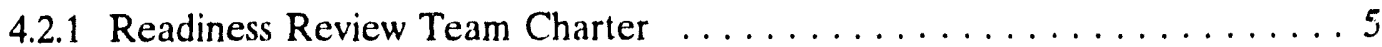

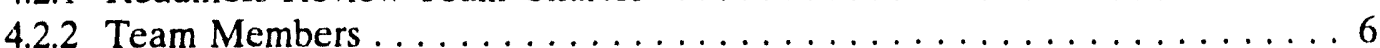

4.3 THE TEAM-BOARD INTERFACE $\ldots \ldots \ldots \ldots \ldots \ldots \ldots \ldots \ldots \ldots \ldots \ldots \ldots$

5. REVIEW METHODOLOGY AND CRITERIA $\ldots \ldots \ldots \ldots \ldots \ldots \ldots \ldots \ldots$

Appendix A. READINESS REVIEW TEAM CRITERIA . . . . . . . . . A-1

Appendix B. READINESS REVIEW BOARD CRITERIA $\ldots \ldots \ldots \ldots \ldots \ldots \ldots$ B-1 


\section{ABBREVIATIONS}

$\begin{array}{ll}\text { CWP } & \text { Contract Work Plan } \\ \text { DOE } & \text { U.S. Department of Energy } \\ \text { ER } & \text { Environmental Restoration } \\ \text { HP } & \text { Health Physics } \\ \text { NEPA } & \text { National Environmental Policy Act } \\ \text { ORNL } & \text { Oak Ridge National Laboratory } \\ \text { P\&E } & \text { Plant and Equipment Division } \\ \text { QA } & \text { quality assurance } \\ \text { RRB } & \text { Readiness Review Board } \\ \text { RRT } & \text { Readiness Review Team } \\ \text { SSHP } & \text { Site Safety and Health Plan } \\ \text { WAG } & \text { Waste Area Grouping }\end{array}$




\section{EXECUTIVE SUMMARY}

This Readiness Review Plan was prepared by the Waste Area Grouping (WAG) 11 Site Project Readiness Review Team as an overview of the Interim Remedial Action on Surface Debris in WAG 11 project at Oak Ridge National Laboratory, including major readiness milestones, criteria development methodology, and a list of events to occur as part of the review process for determining readiness for each project phase.

Other subjects include project support, site background and logistics of remedial action, and program management. 


\section{INTRODUCTION}

\subsection{PLAN OVERVIEW}

Martin Marietta Energy Systems, Inc., (Energy Systems) Policy GP-24, Operation Readiness Process, requires activities to follow a formal, focused, and comprehensive readiness process to determine the activity's readiness to proceed to the next increment of work when management determines that it is necessary. Policy GP-24 is aimed at reducing the risks that threaten mission success and requires a management-approved "readiness plan" to be issued that (1) describes the activity under review, (2) defines the scope of the process, (3) identifies the team members, (4) establishes organizational responsibilities, (5) defines the methodolozy and criteria to be used for determining readiness, and (6) defines the events that must take place to complete the process. The Waste Area Grouping (WAG) 11 Interim Remedial Action of Surface Debris project does not require the formal, focused, and comprehensive process, but will comply with the intent of GP-24 and Environmental Restoration Division Procedure ER/C-P1610, Conducting Project Readiness Reviews.

This plan was prepared by the Oak Ridge National Laboratory (ORNL) WAG 11 Site Project Readiness Review Team (RRT), which was established by the WAG 11 Program Manager to provide the ORNL Environmental Restoration (ER) Program Site Readiness Review Board (RRB) with information on the project team's plan for ensuring that construction activities associated with the project (as defined by the scope of this plan) will he ready to begin when the readiness review process is complete. This plan, along with progress reports on the project's readiness which are to be prepared by the review team, will enable the ER Program Site RRB to conduct its independent assessment of the project's readiness successfully and salely in accordance with the project's ofjectives.

This plan provides an overview of the project, the major milestones that must be accomplished for readiness, the methodology used to develop the criteria, and the events that must take place as part of the review process to determine readiness for each phase of the project. The readiness review schedule will be kept by the Engineering Project Manager, D. L. Garrett, and is available for review at the ORNL Project Engineering offices.

\subsection{PLAN SCOPE}

Before the project can be initiated, there must be documented evidence that

- the U.S. Environmental Protection Agency and the Tennessee Department of Environment and Conservation have approved the remedial action work plan;

- applicable permits and environmental documentation have been issued and procedures are in place specifically addressing the conduct of the project;

- Safety, Industrial Hygiene, Environmental Management, Health Physics, Engineering, Security, Quality Assurance (QA), Plant and Equipment (P\&E), and Waste Management personnel have reviewed and their comments have been incorporated into the project specifications and plans; 
- materials, facilities, and equipment to be used to perform the remedial action have been identified;

- a records system is in place; and

- all project documentation has been completed.

This plan has been prepared to ensure the safe and successful conduct of the project after these requirements have been satisfied. 


\section{PROJECT SUPPORT}

Energy Systems support for this effort will consist of organizations from ORNL, including Health Physics, Safety, Industrial Hygiene, Plant Engineering, P\&E, the ER Program, the Environmertal Management Department, and the Waste Management Division. 


\section{SITE BACKGROUND AND LOGISTICS OF REMEDIAL ACTION}

White Wing Scrap Yard (WAG 11), 1 mile east of the intersection of Highways 58 and 95, is in the McNew Hollow area just north of Pine Ridge. The site covers $~ 30$ acres (12 ha). The scrap yard was used for aboveground storage of scrap and debris from the early 1950s through the mid-1960). The Oak Ridge Gaseous Diffusion Plant (now the K-25 Site) used the northwest side of the site; the Y-12 Plant used the northeast side; and ORNL used the portion south of Hot Yard Road.

WAG 11 received a variety of sizes and types of equipment and material, such as steel tanks, vehicles, metal supports, glass, graphite, concrete, plastic, wood, and composite materials. The entire storage area was fenced during its active use; however, the fence was removed during cleanup operations which began in 1966. Most of the larger scrap was removed from the surface of WAG 11 during preparation for a road relocation in the late 1960s and early 1970s. The scrap, debris, and some soils that were removed from WAG 11 were disposed of in ORNL Solid Waste Storage Area 5. Some large pieces and a large quantity of small debris still remain scattered throughout the site. To exclude hunters from the site, the scrap yard was roped and placarded on November 10, 1989, with "Controlled Area" signs at 50-ft intervals and with Tennessee Wildlife Resources Agency safety zone signs at $100-\mathrm{ft}$ intervals.

All of WAG 11 is thickly vegetated. A forest of small pine trees covers about $30 \%$ of the site, while the remaining area is covered by mixed grass, brush, and young hardwoods. Aerial photographs from 1967 and 1974 show that little vegetation was present during the cleanup activities of those periods.

Approximately $10,000 \mathrm{ft}^{3}$ of debris will be manually collected from the surface of WAG 11. Lead surface debris (small pieces) and any vessels containing liquid will be segregated from the other debris. The remaining debris will then be segregated (detectable vs nondetectable radioactivity), collected and placed in covered dump trucks, boxes, or plastic bags and transported to WAG 6 for storage in Environmental Restoration underground silos. 


\section{PROGRAM MANAGEMENT}

The ORNL ER Program Manager (H. L. Boston), the ORNL ER Program Quality Assurance Specialist (P. A. Schrandt), and the WAG 11 Program Manager (C. A. Bednarz) have identified a need for a readiness review of this project, as required in ER/C.P1610, Conducting Project Readiness Reviews. The RRT has been appointed and is directly responsible for monitoring the project's readiness for operation. The WAG 11 Program Manager is responsible for evaluating the readiness review plan, coordinating approval of the plan, and requesting that the ER Program Site RRB be convened to verify the project's readiness to proceed to the required remedial action work.

\subsection{THE ENVIRONMENTAL RESTORATION READINESS REVIEW BOARD}

\subsubsection{The Readiness Review Board Charter}

As specified in ER/C-P1610, Conducting Project Readiness Reviews, the ER Program Site RRB is an independent group appointed by the ORNL ER Program Manager. The group has been established to (1) provide independent oversight of the readiness review process, (2) verify the validity of the readiness process, (3) evaluate the risk of proceeding to the next work activity, and (4) recommend actions regarding proceeding that are supported by readiness criteria.

\subsubsection{Environmental Restoration Program Site Readiness Review Board Members}

The RRB members are

- D. E. Miller, Environmental Sciences Division;

- D. M. Carden, U. S. Department of Energy (DOE);

- A. J. Kuhaida, ORNL-ER Chairman; and

- G. R. Hudson, DOE.

\subsection{THE READINESS REVIEW TEAM}

\subsubsection{The Readiness Revicw Team Charter}

The RRT is a management-appointed multidisciplinary group that has been established to (1) evaluate the state of readiness for removal of surface debris at WAG 11 (to proceed to operation and maintenance activities); (2) identify and validate supportive, objective evidence of readiness; and (3) assist the WAG 11 Program Manager in presenting the evidence of readiness to the ER Program Site RRB.

Specific responsibilities include

- preparing the readiness review plan,

- using appropriate techniques to ensure full coverage of all activities,

- preparing the readiness criteria,

- identifying and verifying the visible objective evidence, 
- monitoring and determining the state of readiness and reporting this information to the RRE and the ORNL ER Program Site Manager, and

- making presentations to the ER Site Program RRB $n$ the state of readiness.

The team's activities will include review of the readiness of facilities and equipment, materials, personnel and training, plans, permits and procedures, and support services.

\subsubsection{Team Members}

The RRT members are

- C. A. Bednarz, ORNL ER WAG 13 Program Manager;

- S. N. Burman, Site Safety and Health Officer;

- P. M. Dawson, Engineering;

- L. Holder, Jr., Waste Management and Remedial Action;

- M. E. Garcia and R. L. Jeffers, Health Physics;

- D. L. Garrett, Engineering;

- R. B. Knott, Engineering Construction;

- G. R. Larson, Solid Waste Operations;

- G. L. Livengood, Transportations Operations Management System;

- S. D. McGhee, RAMSPAC;

- C. S. Mims, DOE;

- A. W. Saulsbury, Hazardous Waste Operations and Emergency Response/Industrial Hygiene;

- J. L. Sluder, P\&E; and

- M. A. Woody, QA.

\subsection{THE TEAM-BOARD INTERFACE}

The RRT is responsible for providing the ER Program Site RRB with the verification data necessary to validate the readiness for proceeding to the next increment of work. The RRT will make this information available in progress reports and meetings held to review readiness.

The ER Program Site R.RB will be responsible for reviewing the data, evaluating the risks associated with operation, and making recommendations regarding the pioject's readiness for initiation. 


\section{REVIEW METHODOLOGY AND CRITERIA}

The readiness review process is a management tool that establishes and verifies the state of readiness of an activity. The process began with the creation of this plan and the identification of initial readiness criteria. Detailed criteria will be compiled by the team, approved by the RRB, and approved for field mobilization. The process concludes with the ER Program Siie RRB's documented decision on the project's state of readiness for operation and any accompanying recommendations that need to be addressed by the program management.

The readiness review criteria are the standaras by which the removal of surface debris from WAG 11 will be judged ready to start. The readiness review criteria are being defined according to their specific applicability to the activity, and the generic criteria have been defined for events that must be accomplished to achieve readiness.

The RRT has met on several occasions and has identified, discussed, assigned, and resolved action items from the review criteria listed in Appendix A. While the Appendix A criteria cover a broad spectrum, the actual readiness review will be restricted to critical pathway criteria listed in Appendix B. These criteria are the National Environmental Policy Act (NEPA), the QA Plan, the Waste Management plan, the Performance Specification, the Site Safety Health Plan, and transportation concerns. 
Appendix A

READINESS REVIEW TEAM CRITERIA 
Table A 1. Operational Readiness Matrix for WAG 11 Surface Debris Cleanup-Ready to Start

\begin{tabular}{|c|c|c|c|c|c|}
\hline & $\begin{array}{l}\text { Review } \\
\text { criteria }\end{array}$ & $\begin{array}{c}\text { Responsible } \\
\text { individual }\end{array}$ & $\begin{array}{c}\text { Date } \\
\text { complete }\end{array}$ & Criteria description & Comments \\
\hline 1 & $\begin{array}{l}\text { Ready to start } \\
\text { remediation }\end{array}$ & & & & $\begin{array}{l}\text { RRB to make } \\
\text { recommendations on readiness }\end{array}$ \\
\hline 1.1 & Personnel & J. Sluder, RRT & & $\begin{array}{l}\text { Appropriate P\&E personnel } \\
\text { have heen identified and will be } \\
\text { listed in CWP. }\end{array}$ & CWP to be issued \\
\hline 1.1 .1 & $\begin{array}{l}\text { P\&E Field Supervisor } \\
\text { available }\end{array}$ & R. Wright, RRT & & $\begin{array}{l}\text { P\&E will furnish field } \\
\text { supervisor, and organizational } \\
\text { chart will be in CWP. }\end{array}$ & CWP to be issued \\
\hline 1.1.1.2 & Staffed & J. Sluder, RRT & & $\begin{array}{l}\text { P\&E has staff available and } \\
\text { committed to the project. }\end{array}$ & $\begin{array}{l}\text { J. Sluder will supply } \\
\text { documentation and key } \\
\text { personnel list; will use CWP } \\
\text { list. }\end{array}$ \\
\hline 1.1.1.3 & Melion Valley Access & L. Holder, RRT & & $\begin{array}{l}\text { P\&E truck drivers need access } \\
\text { to WAG } 6 .\end{array}$ & \\
\hline 1.1.1.4 & $\begin{array}{l}\text { Health Physics } \\
\text { preparation }\end{array}$ & $\begin{array}{l}\text { M. E. Garcia, } \\
\text { RRT }\end{array}$ & & $\begin{array}{l}\text { ES provides HP coverage and } \\
\text { personnel completed whole } \\
\text { body counts and related hems. }\end{array}$ & $\begin{array}{l}\text { Covered in the SSHP. Energy } \\
\text { Systems HP support for RA } \\
\text { and loading boxes; R. Jeffers. } \\
\text { (M. E. Garcia). Complete } \\
\text { when SSHP is issued. }\end{array}$ \\
\hline 1.1 .2 & $\begin{array}{l}\text { Engineering } \\
\text { construction support }\end{array}$ & $\begin{array}{l}\text { D. L. Garrett, } \\
\text { RRT }\end{array}$ & $9 / 3 / 93$ & $\begin{array}{l}\text { Engineering construction } \\
\text { support is identified and } \\
\text { adequately staffed }\end{array}$ & $\begin{array}{l}\text { Engincering XMTL } \\
\text { WAG 11-19, dated 9/3/93 }\end{array}$ \\
\hline 1.1 .3 & Title III support & $\begin{array}{l}\text { R.B. Knott, } \\
\text { RRT }\end{array}$ & & $\begin{array}{l}\text { Letter from Construction } \\
\text { Engineering stating personnel } \\
\text { are available }\end{array}$ & $\begin{array}{l}\text { Letter needed from } \\
\text { Construction Manager }\end{array}$ \\
\hline 1.1 .4 & $\begin{array}{l}\text { Technical oversight } \\
\text { support }\end{array}$ & $\begin{array}{l}\text { C.A. Bednarz, } \\
\text { D.L. Garrett }\end{array}$ & & $\begin{array}{l}\text { Environmental Restoration and } \\
\text { Engineering will provide } \\
\text { oversight. }\end{array}$ & Letter needed from ER \\
\hline
\end{tabular}


Table A1 (continuod)

\begin{tabular}{|c|c|c|c|c|c|}
\hline & $\begin{array}{l}\text { Review } \\
\text { criteria }\end{array}$ & $\begin{array}{l}\text { Responsible } \\
\text { individual }\end{array}$ & $\begin{array}{c}\text { Date } \\
\text { oomplete }\end{array}$ & Criteria description & Comments \\
\hline 1.1 .5 & $\begin{array}{l}\text { Training Requirements } \\
\text { Matrix }\end{array}$ & $\begin{array}{l}\text { W.D. Davis, } \\
\text { RRT }\end{array}$ & & $\begin{array}{l}\text { Training criteria have been } \\
\text { identified for workers, visitors, } \\
\text { inspectors, hauler, and } \\
\text { supervisors (see SSHP). }\end{array}$ & Complete when SSHP issued \\
\hline 1.1 .6 & $\begin{array}{l}\text { Health and safety } \\
\text { suppont }\end{array}$ & $\begin{array}{l}\text { W.D. Davis. } \\
\text { RRT }\end{array}$ & & $\begin{array}{l}\text { Site Safety and Health Plan has } \\
\text { been approved and issued. }\end{array}$ & \\
\hline 1.1.6.1 & Industrial hygiene & $\begin{array}{l}\text { M.S. Slater, } \\
\text { A.Saulsbury, } \\
\text { RRT, } \\
\text { RRB }\end{array}$ & & $\begin{array}{l}\text { Industrial Hygiene has } \\
\text { identified key personnel for } \\
\text { oversight support. }\end{array}$ & $\begin{array}{l}\text { Letter (E-mail; needed from } \\
\text { AWS and MSS of iH }\end{array}$ \\
\hline 1.1 .6 .2 & Health physies & $\begin{array}{l}\text { M.E. Garcia, } \\
\text { RRT, } \\
\text { RRB }\end{array}$ & & $\begin{array}{l}\text { Health physics has identified } \\
\text { key personnei who will support } \\
\text { project }\end{array}$ & MEG/RLJ to send E-mail \\
\hline 1.1.7 & Quality assurance & J. Sluder, RRT & & $\begin{array}{l}\text { Verification of P\&E QA } \\
\text { requirements and program }\end{array}$ & $\begin{array}{l}\text { JLS to send E-mail stating } \\
\text { work will be performed in } \\
\text { accord with P\&E QA program }\end{array}$ \\
\hline 1.2 & $\begin{array}{l}\text { Procedures and } \\
\text { controls }\end{array}$ & & & & \\
\hline 1.21 & $\begin{array}{l}\text { Health and Safety } \\
\text { Work Requirements } \\
\text { Checklist issued }\end{array}$ & $\begin{array}{l}\text { R.B. Knott, } \\
\text { RRT }\end{array}$ & & $\begin{array}{l}\text { Health and Safety Wort } \\
\text { Requirements Checklist has } \\
\text { been released }\end{array}$ & $\begin{array}{l}\text { R. B. Knott to provide } \\
\text { checklist to P\&E }\end{array}$ \\
\hline 1.2 .2 & NEPA* documentation & $\begin{array}{l}\text { D.L. Garrett, } \\
\text { RRT }\end{array}$ & 9/8/93 & $\begin{array}{l}\text { NEPA maintenance } C X \text { has } \\
\text { been approved and issued. }\end{array}$ & $\begin{array}{l}\text { Engineering XMTL } \\
\text { WAG 11-20, dated 9/8/93 }\end{array}$ \\
\hline 1.2 .3 & $\begin{array}{l}\text { Environmental review } \\
\text { checklist summary } \\
\text { complete }\end{array}$ & $\begin{array}{l}\text { D.L. Garreth, } \\
\text { RRT }\end{array}$ & 9/8/93 & $\begin{array}{l}\text { Documentation checklist is } \\
\text { complete and issued. }\end{array}$ & $\begin{array}{l}\text { Engineering XMTL } \\
\text { WAG 11-20, dated 9/893 }\end{array}$ \\
\hline
\end{tabular}


Table $\Lambda 1$ (continued)

\begin{tabular}{|c|c|c|c|c|c|}
\hline & $\begin{array}{l}\text { Review } \\
\text { criteria }\end{array}$ & $\begin{array}{l}\text { Responsible } \\
\text { individual }\end{array}$ & $\begin{array}{c}\text { Date } \\
\text { complete }\end{array}$ & Criteria description & Comments \\
\hline 1.24 & $\begin{array}{l}\text { Project review } \\
\text { summary letter issued }\end{array}$ & $\begin{array}{l}\text { D.L Garrett, } \\
\text { RRT }\end{array}$ & $9 / 8 / 93$ & $\begin{array}{l}\text { Documentation checklist is } \\
\text { complete and issued. }\end{array}$ & $\begin{array}{l}\text { Engineering XMTL } \\
\text { WAG 11-20, dated 9/8/93 }\end{array}$ \\
\hline 1.2 .5 & $\begin{array}{l}\text { Excavation/ } \\
\text { penetration permit }\end{array}$ & $\begin{array}{l}\text { D.L Garrelt, } \\
\text { RRT }\end{array}$ & $9 / / 93$ & Not required & $\begin{array}{l}\text { No excavation nor penetrations } \\
>12 \text { in. }\end{array}$ \\
\hline 1.2 .6 & $\begin{array}{l}\text { Davis-Bacon } \\
\text { determination } \\
\text { complete }\end{array}$ & $\begin{array}{l}\text { D.L Garretr, } \\
\text { RRT }\end{array}$ & $9 / 3 / 93$ & $\begin{array}{l}\text { Davis Bacon form has been } \\
\text { completed and issued. }\end{array}$ & $\begin{array}{l}\text { Engineering XMTL } \\
\text { WAG 11-19, dated 9/3/93 }\end{array}$ \\
\hline 1.2 .7 & $\begin{array}{l}\text { Project management } \\
\text { plan issued }\end{array}$ & $\begin{array}{l}\text { D.L. Garrett, } \\
\text { RRT }\end{array}$ & $8 / 25 / 93$ & $\begin{array}{l}\text { Project Management Plan has } \\
\text { been approved and issued. }\end{array}$ & $\begin{array}{l}\text { Engincering XMTL } \\
\text { WAG 11-14, dated 8/25/93 }\end{array}$ \\
\hline 1.2 .8 & $\begin{array}{l}\text { Risk assessment/plan } \\
\text { issued }\end{array}$ & $\begin{array}{l}\text { D.L Garrett, } \\
\text { RRT }\end{array}$ & $3 / 31 / 93$ & $\begin{array}{l}\text { Risk Assessment Plan has been } \\
\text { approved and issued. }\end{array}$ & $\begin{array}{l}\text { Engineering XMTL } \\
\text { WAG 11-10, daied 3/31/93 }\end{array}$ \\
\hline 1.29 & $\begin{array}{l}\text { Best management } \\
\text { practice plan issued }\end{array}$ & $\begin{array}{l}\text { D.L Garrett, } \\
\text { RRT }\end{array}$ & $8 / 20 / 93$ & $\begin{array}{l}\text { Best management plan has been } \\
\text { approved and issued. }\end{array}$ & $\begin{array}{l}\text { Issued as part of performance } \\
\text { specification; Engineering } \\
\text { XMTL WAG 11-93-6 } \\
\text { (93-0496), dated 8/20/93 }\end{array}$ \\
\hline 1.2.10 & $\begin{array}{l}\text { Site health and safety } \\
\text { plan issued }\end{array}$ & $\begin{array}{l}\text { W.D. Davis, } \\
\text { RRT }\end{array}$ & & $\begin{array}{l}\text { SSHP has been approved and } \\
\text { issued. }\end{array}$ & \\
\hline 1.211 & Safety review issued & $\begin{array}{l}\text { D.L. Garret?. } \\
\text { RRT }\end{array}$ & $8 / 4 / 92$ & $\begin{array}{l}\text { Safety review has been } \\
\text { approved and issued. }\end{array}$ & $\begin{array}{l}\text { Engineering XMTL XSSE-436, } \\
\text { dated 8/4/92 }\end{array}$ \\
\hline 1.2 .12 & $\begin{array}{l}\text { Project waste } \\
\text { management plan } \\
\text { issued }\end{array}$ & $\begin{array}{l}\text { D.L. Garrett, } \\
\text { RRT }\end{array}$ & & $\begin{array}{l}\text { Project Waste Management } \\
\text { Plan has been approved and } \\
\text { issued. }\end{array}$ & \\
\hline 1.2 .13 & $\begin{array}{l}\text { Projects Records plan } \\
\text { issued }\end{array}$ & $\begin{array}{l}\text { D.L Garretl, } \\
\text { RRT }\end{array}$ & $12 / 22 / 92$ & $\begin{array}{l}\text { Project Records Plan has been } \\
\text { approved and issued. }\end{array}$ & $\begin{array}{l}\text { Engineering XMTL } \\
\text { WAG 11-04, dated 12/22/93 }\end{array}$ \\
\hline
\end{tabular}


Table A.i (continuod)

\begin{tabular}{|c|c|c|c|c|c|}
\hline & $\begin{array}{l}\text { Review } \\
\text { criteria }\end{array}$ & $\begin{array}{l}\text { Respoesible } \\
\text { individual }\end{array}$ & $\begin{array}{c}\text { Date } \\
\text { complete }\end{array}$ & Criteria description & Commenents \\
\hline 1.2 .14 & $\begin{array}{l}\text { Regulatory } \\
\text { concurrence obtained }\end{array}$ & $\begin{array}{l}\text { C.S. Mims, } \\
\text { RRT. } \\
\text { RRB }\end{array}$ & $8 / 31 / 93$ & $\begin{array}{l}\text { Remedial Action Work Plan } \\
\text { has heen approved by both U.S. } \\
\text { Environmental Protection } \\
\text { Agency and Tennessee } \\
\text { Department of Environmental } \\
\text { Conservation. }\end{array}$ & $\begin{array}{l}\text { Engineering XMTL WAG } \\
11-18 \text {, dated } 8 / 31 / 93 \text {. }\end{array}$ \\
\hline 1.2 .17 & $\begin{array}{l}\text { Quality assurance plan } \\
\text { issued }\end{array}$ & D.L. Garrett & & $\begin{array}{l}\text { QA Plan has been approved } \\
\text { and issued. }\end{array}$ & \\
\hline 1.2 .18 & $\begin{array}{l}\text { Verification and } \\
\text { documentation } \\
\text { methods defined }\end{array}$ & D.L. Garrett & $8 / 20 / 93$ & $\begin{array}{l}\text { Performance specification } \\
\text { contains task completion } \\
\text { verification. }\end{array}$ & $\begin{array}{l}\text { Engineering XMTL WAG } \\
11-92-6(93-0496), \text { dated } \\
8 / 20 / 93\end{array}$ \\
\hline 1.2 .19 & $\begin{array}{l}\text { Lessons learned } \\
\text { investigated }\end{array}$ & $\begin{array}{l}\text { D.L. Garrett, } \\
\text { RRT. } \\
\text { RRB }\end{array}$ & & $\begin{array}{l}\text { Data base regarding excavations } \\
\text { has been accessed. }\end{array}$ & Letter DLG to RRT dated \\
\hline 1.3 & $\begin{array}{l}\text { Facilities and } \\
\text { equipment }\end{array}$ & & & & \\
\hline 1.3 .1 & P\&E equipment & $\begin{array}{l}\text { J. L. Sluder, } \\
\text { RRT }\end{array}$ & & $\begin{array}{l}\text { An equipment list has been } \\
\text { compiled of applicable } \\
\text { equipment. }\end{array}$ & W.D. Davis to provide in CWP \\
\hline 1.3 .2 & $\begin{array}{l}\text { Industrial hygiene } \\
\text { instrumentation }\end{array}$ & $\begin{array}{l}\text { Brad Copeland, } \\
\text { RRT, } \\
\text { RRB }\end{array}$ & & $\begin{array}{l}\text { CWP identified air monitoring } \\
\text { equipment }\end{array}$ & CWP to be issued by \\
\hline 1.3 .3 & $\begin{array}{l}\text { Radiation } \\
\text { instrumentation }\end{array}$ & $\begin{array}{l}\text { M.E. Garcia, } \\
\text { RRT, } \\
\text { RRB }\end{array}$ & & Energy Systems HP coverage & $\begin{array}{l}\text { Letter needed to DLG listing } \\
\text { equipment and personnel } \\
\text { availability }\end{array}$ \\
\hline 1.3 .4 & Waste containers & $\begin{array}{l}\text { B.McClelland, } \\
\text { RRT, } \\
\text { RRB }\end{array}$ & & & \\
\hline
\end{tabular}


Table A.1 (continued)

\begin{tabular}{|c|c|c|c|c|c|}
\hline & $\begin{array}{l}\text { Revicw } \\
\text { criteria }\end{array}$ & $\begin{array}{l}\text { Responsible } \\
\text { individual }\end{array}$ & $\begin{array}{c}\text { Date } \\
\text { complete }\end{array}$ & Criteria description & Comencrets \\
\hline 1.3 .5 & $\begin{array}{l}\text { Waste staging facility } \\
\text { (WAG 11) }\end{array}$ & $\begin{array}{l}\text { C.A. Bednarz, } \\
\text { RRT }\end{array}$ & & $\begin{array}{l}\text { Letter from Environmental } \\
\text { Compliance establishing criteria } \\
\text { for the construction of staging } \\
\text { areas }\end{array}$ & $\begin{array}{l}\text { C. Bednarz to provide letter to } \\
\text { D. L Garrett by }\end{array}$ \\
\hline 1.3 .6 & Support trailers & $\begin{array}{l}\text { J. Sluder, } \\
\text { RRT, } \\
\text { RRB } \\
\end{array}$ & & $\begin{array}{l}\text { Site layout map or plan } \\
\text { illustrates location of trailers. }\end{array}$ & $\begin{array}{l}\text { W. D. Davis to provide site } \\
\text { plan in CWP }\end{array}$ \\
\hline 1.3 .7 & $\begin{array}{l}\text { Decontamination } \\
\text { equipment }\end{array}$ & $\begin{array}{l}\text { J. Sluder, } \\
\text { RRT, } \\
\text { RRB }\end{array}$ & & $\begin{array}{l}\text { Decontamination equipment } \\
\text { identified as being available }\end{array}$ & $\begin{array}{l}\text { JLS to provide letter (E-mail } \\
\text { to DLG stating temporary } \\
\text { decontamination facilities will } \\
\text { be available at staging area) }\end{array}$ \\
\hline 1.3 .8 & $\begin{array}{l}\text { Personnel safety } \\
\text { equipment }\end{array}$ & $\begin{array}{l}\text { J. L Sluder, } \\
\text { RRT, } \\
\text { RRB } \\
\end{array}$ & & $\begin{array}{l}\text { SSHP is approved and issued; } \\
\text { Lists PPE requirements }\end{array}$ & SSHP to be issued \\
\hline 1.3 .9 & Silo construction & $\begin{array}{l}\text { B.McClelland, } \\
\text { RRT, } \\
\text { RRB }\end{array}$ & & & $\begin{array}{l}\text { O. Larson to provide all silo } \\
\text { info }\end{array}$ \\
\hline 1.3 .11 & Transportation & $\begin{array}{l}\text { J. Sluder, } \\
\text { RRT, } \\
\text { RRB }\end{array}$ & & $\begin{array}{l}\text { P\&E has resources and } \\
\text { approvals to transpont } \\
\text { radioactive waste on public } \\
\text { highways. }\end{array}$ & $\begin{array}{l}\text { JLS to provide letter to DLG } \\
\text { (e-mail) verifying resources } \\
\text { and approvals }\end{array}$ \\
\hline 1.3.14 & Tie-down plan & $\begin{array}{l}\text { J. Sluder, } \\
\text { RRT, } \\
\text { RRB }\end{array}$ & & $\begin{array}{l}\text { Tie-down plan prepared and } \\
\text { approved by commitice and } \\
\text { issued }\end{array}$ & $\begin{array}{l}\text { Provide plan and approval } \\
\text { letter to D. L Garrett }\end{array}$ \\
\hline
\end{tabular}

CWP -oontract work plan.

SSHP Site Safety Healh Plan

$P \& E \quad-P$ lant and Equipment.

HP Hiealth Physics. 
Appendix B

READINESS REVIEW BOARD CRITERIA 
Table B.1. Readiness Revicw Board Criteria

\begin{tabular}{|c|c|c|c|c|c|}
\hline & $\begin{array}{l}\text { Review } \\
\text { criteria }\end{array}$ & $\begin{array}{l}\text { Responsible } \\
\text { individual }\end{array}$ & $\begin{array}{c}\text { Date } \\
\text { complete }\end{array}$ & Criteria description & Combersts \\
\hline \multicolumn{6}{|c|}{ 1.1 Health and safety support } \\
\hline 1.2 & $\begin{array}{l}\text { NEPA documentation } \\
\text { approved }\end{array}$ & & & & \\
\hline 1.3 & $\begin{array}{l}\text { Project Waste Management } \\
\text { Plan issued }\end{array}$ & & & & \\
\hline 1.4 & $\begin{array}{l}\text { Sampling and Analysis Plan } \\
\text { complete }\end{array}$ & & & & \\
\hline 1.5 & $\begin{array}{l}\text { Quality Assurance Plan } \\
\text { issued }\end{array}$ & & & & \\
\hline 1.6 & Transportation & & & & \\
\hline 1.7 & $\begin{array}{l}\text { TOMS activities, } \\
\text { transportation contract } \\
\text { carrier }\end{array}$ & & & & \\
\hline 1.8 & $\begin{array}{l}\text { Performance specification } \\
\text { document }\end{array}$ & & & & \\
\hline
\end{tabular}




\section{DISTRIBUTION}

1. C. A. Bednarz

2. H. L. Boston

3. S. N. Burman

4. P. M. Dawson

5. M. E. Garcia

6. D. L. Garrett

7. L. Holder, Jr.

8. L. D. Hyde

9. R. L. Jeffers

10. R. B. Knott

11. A. J. Kuhaida

12. G. R. Larson

13. G. L. Livengood

14-16. D. M. Matteo

17. S. D. McOhee

18. D. E. Miller

19-20. P. T. Owen

21. A. W. Saulsbury

22. P. A. Schrandt

23. J. L. Sluder

24. P. S. Wood

25. M. A. Woody

26. Central Research Library

27-29. ORNL ER Document Management Center-RC

30-32. Central ER Document Management Center

33. Laboratory Records Dept.

34. ORNL Patent Section

35. Office of Assistant Manager for Energy Research and Development, DOE Oak Ridge Operations Office, P.O. Box 2001, Oak Ridge, TN 37831-8600

36. R. C. Sleeman, DOE Oak Ridge Operations Office, P.O. Box 2001, Oak Ridge, TN 37831-8541

37. J. T. Sweeney, DOE Oak Ridge Operations Oftice, P.O. Box 2001, Oak Ridge, TN $37831-8541$

38. D. W. Swindle, Radian Corporation, 120 South Jefferson Circle, Oak Ridge, TN 37830

39-40. Office of Scientific and Technical Information, P.O. Box 62, Oak Ridge, TN 37831 

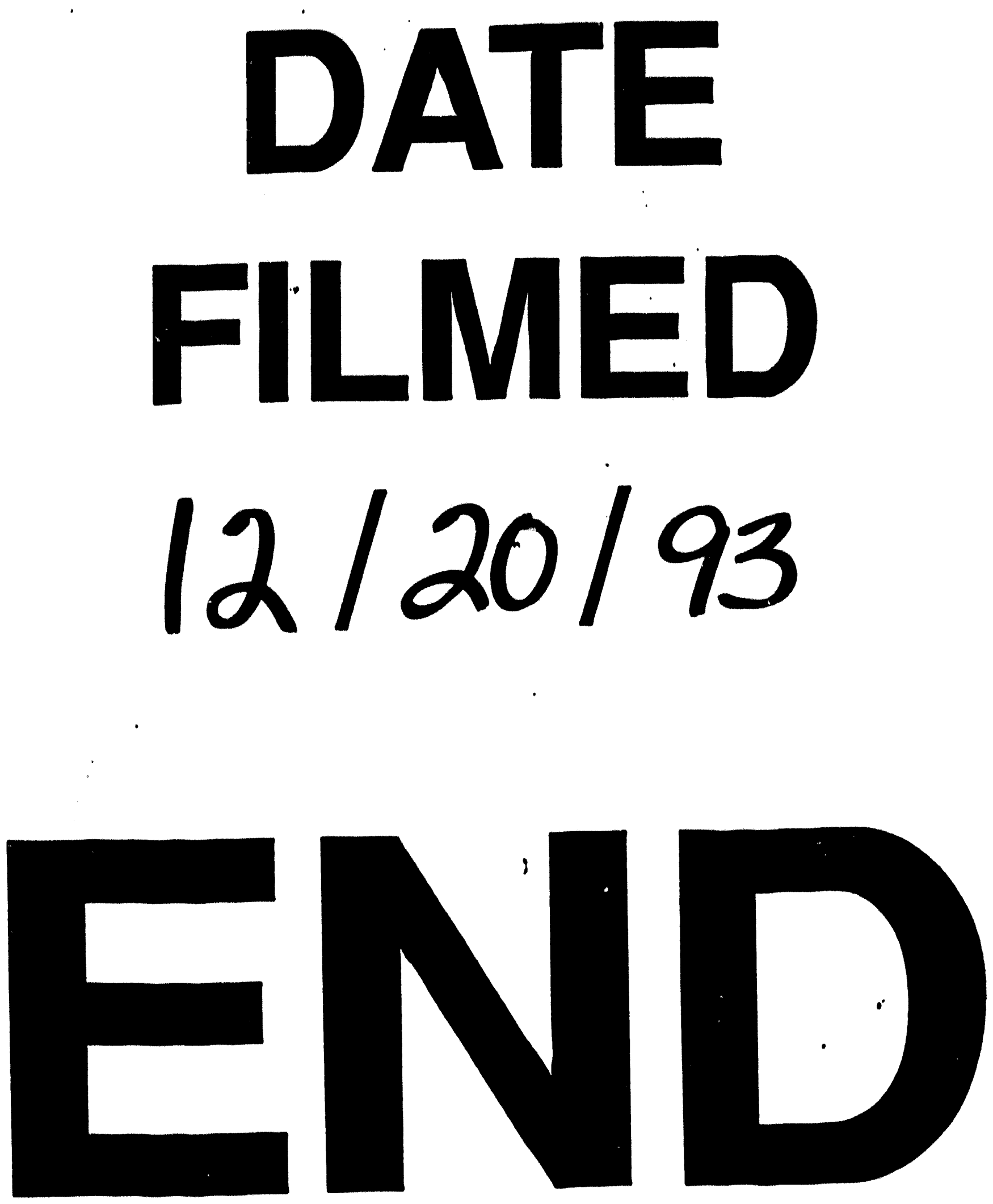
